\title{
Kajian Perhitungan Beban Pencemaran Sungai Cisangkuy di Cekung Bandung dari Sektor Pertanian
}

\author{
Hisky Robinson Sampe ${ }^{1}$, Iwan Juwana ${ }^{1}$, Dyah Marganingrum² \\ ${ }^{1}$ Jurusan Teknik Lingkungan, Fakultas Teknik Sipil dan Perencanaan, ITENAS, Bandung \\ ${ }^{2}$ Pusat Penelitian Geoteknologi, Lembaga Ilmu Pengetahuan Indonesia (LIPI), Bandung \\ Email: Robinson21778@gmail.com
}

\begin{abstract}
ABSTRAK
Sungai Cisangkuy merupakan bagian dari anak sungai Citarum Hulu yang terdapat di kawasan Cekungan Bandung, yang melewati wilayah administrasi Kabupaten Bandung. Aktivitas manusia seperti kegiatan pertanian mempengaruhi kualitas air yaitu berpotensi memberikan beban pencemaran BOD, TSS, Total $N$ dan Total P di Sungai Cisangkuy. Penelitian tentang beban pencemaran dilakukan karena tidak tersedianya informasi mengenai daya tampung beban pencemaran dari sektor pertanian. Penelitian ini bertujuan untuk mengetahui jumlah beban pencemaran yang masuk ke Sungai Cisangkuy, sehingga melalui penelitian ini akan diketahui besaran beban pencemaran yang masuk ke Sungai Cisangkuy khususnya dari sektor pertanian. Analisis kualitas air dilakukan dengan menggunakan metode indeks pencemaran. Perhitungan potensi beban pencemaran dilakukan dengan menggunakan pendekatan faktor emisi. Beban pencemaran eksisting kemudian dibandingkan dengan beban pencemaran maksimum yang digunakan sebagai baku mutu daya tampung beban pencemaran sungai. Hasil perhitungan menunjukkan bahwa trend pencemaran sungai Cisangkuy cenderung meningkat dari tahun 2012-2015. Indeks Pencemaran Sungai Cisangkuy masuk dalam kategori Cemar Sedang dengan nilai 7,07, dan beban pencemaran total dari sektor pertanian bernilai 1,55 ton/hari.
\end{abstract}

Kata kunci: Cisangkuy, Indeks Pencemaran, Pertanian, Beban Pencemaran

\begin{abstract}
Cisangkuy River is part of the upstream Citarum tributary in the area of Bandung Basin, which passes the administrative area of Bandung regency. Human activities such as agricultural activities affect the quality of water that potentially provide pollution load BOD, TSS, Total $N$ and Total $P$ in the Cisangkuy River. Research on pollution load is needed because the inavailability of information about pollution load capacity from agriculture sector. This study aims to determine the amount of pollution load being discharged into the Cisangkuy River from agricultural sector. Water quality analysis is done by using pollution index method. Calculation of potential pollution load is done by using the emission factor approach. Existing pollution loads are then compared with the maximum pollution loads used as the quality standard of river pollution load capacity. The results show that pollution of the river Cisangkuy tends to increase from the year 2012-2015. The Cisangkuy River Pollution Index is categorized as 7.07, and the total pollution load from the agricultural sector is 1.55 tons / day.
\end{abstract}

Keywords: Cisangkuy, Pollution Index, Agricultural, Pollutant Load 


\section{PENDAHULUAN}

Sungai Cisangkuy merupakan salah satu sub Daerah Aliran Sungai (DAS) Citarum Hulu yang ada di Cekungan Bandung. DAS Citarum merupakan salah satu sungai terbesar di Pulau Jawa dengan panjang $\pm 300 \mathrm{~km}$ (Kurniasih, 2002). Sub DAS Cisangkuy yang memiliki total luas $27.733 \mathrm{~km}^{2}$ ini, berada di Kabupaten Bandung, Jawa Barat dan melewati sepuluh kecamatan, yaitu Kecamatan Baleendah, Pameungpeuk, Arjasari, Cangkuang, Banjaran, Cimaung, Ciparay, Pasirjambu, Pangalengan, dan Pacet [1].

Sektor pertanian merupakan sektor yang berpotensi menyebabkan pencemaran di Sungai Cisangkuy dan termasuk dalam sumber pencemar titik. Pencemaran dari sektor pertanian disebabkan oleh pupuk yang terbawa oleh air limpasan menuju Sungai Cisangkuy. Air limpasan ini tidak hanya mengalir di satu titik di Sungai Cisangkuy tetapi dari banyak titik sehingga potensi pencemaran di Sungai Cisangkuy dapat meningkat karena sumber pencemar yang masuk menyebar di setiap titik di Sungai Cisangkuy.

Sampai saat ini belum ada langkah nyata untuk mengurangi pencemaran di Sungai Cisangkuy. Atas dasar inilah perlu dilakukan suatu kajian dan evaluasi mengenai kualitas air dan potensi beban pencemaran sungai Cisangkuy yang terkonsentrasi pada sektor pertanian. Status kualitas air dan besaran potensi beban pencemaran dari sektor pertanian dapat digunakan sebagai acuan penyusunan program pengendalian pencemaran air Sungai Cisangkuy agar sesuai dengan peruntukkannya.

Maksud penelitian ini adalah untuk mengetahui daya tampung beban pencemaran Sungai Cisangkuy dari sektor pertanian. Sedangkan tujuan penelitian ini adalah menganalisis kualitas air, mengidentifikasi parameter beban pencemar, dan melakukan perhitungan beban pencemar di Sungai Cisangkuy. Ruang lingkup dalam penelitian ini adalah pengolahan data sekunder yaitu data kualitas air, debit sungai, dan peta wilayah Sub DAS Cisangkuy menggunakan ArcGIS.

\subsection{Pengambilan Data Sekunder}

\section{METODOLOGI}

Tahapan pengerjaan kajian ini dimulai dari pengambilan data sekunder, di antaranya yaitu data kualitas air, debit, dan beberapa peta seperti peta tata guna lahan, peta sub DAS Citarum Hulu, dan peta pola ruang. Kualitas air dan debit Sungai Cisangkuy di peroleh dari Balai Besar Wilayah Sungai (BBWS) Citarum, Provinsi Jawa Barat. Peta tata guna lahan di peroleh dari Dinas Sumber Daya Air (DSDA) Provinsi Jawa Barat, peta Sub DAS Citarum Hulu di peroleh dari Geoteknologi Lembaga Ilmu Pengetahuan Indonesia (Geotek LIPI) Kota Bandung [1]. Di perlukan data selama kurang lebih lima tahun terakhir untuk mengetahui trend pencemaran air yang terjadi di Sungai Cisangkuy yaitu tahun 2011-2016.

\subsection{Kualitas Air}

Data kualitas air yang ada pada Sungai Cisangkuy merupakan data sampel yang diambil pada beberapa bulan yang dianggap mewakili perbedaan musim selama satu tahun. Meskipun ada data satu tahun yang hanya terdiri atas satu bulan sehingga kurang mewakili perbedaan musim pada tahun tersebut, data kualitas air masing-masing tahun di rata-ratakan sehingga dapat di bandingkan kualitas air masing-masing tahun apakah melebihi baku mutu yang ditentukan atau tidak.

Kualitas air sungai Cisangkuy yang di peroleh ini kemudian di bandingkan dengan baku mutu SK. Gub. Jabar 39/2000 golongan B,C,D. Di dalamnya di jelaskan bahwa golongan B,C,D merupakan gabungan dari golongan $\mathrm{B}$ sebagai peruntukkan air baku air minum, golongan $\mathrm{C}$ sebagai peruntukkan perikanan dan peternakan, dan golongan $\mathrm{D}$ sebagai peruntukkan pertanian, usaha perkotaan, industri, dan pembangkit listrik tenaga air (PLTA). 


\subsection{Status Mutu Air}

Dalam penelitian ini, penentuan status mutu air menggunakan metode Indeks Pencemaran (IP). Penentuan status mutu air dengan metode Indeks Pencemaran diatur dalam sebuah peraturan yaitu Keputusan Menteri Lingkungan Hidup Nomor 115 Tahun 2003 [2] tentang Pedoman Penentuan Status Mutu Air dengan persamaan rumus sebagai berikut:

1. Parameter yang konsentrasinya lebih rendah dari baku mutu, kualitas airnya membaik

$$
\left(\mathrm{C}_{\mathrm{i}} / \mathrm{L}_{\mathrm{ij}}\right)_{\text {baru }}=\frac{\text { konsentrasi }\left(\frac{\mathrm{mg}}{\mathrm{liter}}\right)}{\text { nilai baku mutu }\left(\frac{\mathrm{mg}}{\text { liter }}\right)}
$$

2. Parameter yang konsentrasinya lebih tinggi dari baku mutu, kualitas airnya membaik

$$
\left(\mathrm{C}_{\mathrm{i}} / \mathrm{L}_{\mathrm{ij}}\right)_{\text {baru }}=\frac{\mathrm{C}_{\mathrm{im}}-\mathrm{C}_{\mathrm{i} \text { (hasil pengukuran) }}}{\mathrm{C}_{\mathrm{im}}-\mathrm{L}_{\mathrm{ij}}}
$$

3. Parameter yang memiliki rentang :

$$
\begin{aligned}
& \text { Jika } \mathrm{C}_{\mathrm{i}} \leq \mathrm{L}_{\mathrm{ij}} \text { rata-rata } \\
& \left(\mathrm{C}_{\mathrm{i}} / \mathrm{L}_{\mathrm{ij}}\right)_{\text {baru }}=\frac{\left[\mathrm{C}_{\mathrm{i}}-\left(\mathrm{L}_{\mathrm{ij}}\right)_{\text {rata-rata }}\right]}{\left\{\left(\mathrm{L}_{\mathrm{ij}}\right)_{\text {minimum }}-\left(\mathrm{L}_{\mathrm{ij}}\right)_{\text {rata-rata }}\right\}}
\end{aligned}
$$

- Jika $\mathrm{C}_{\mathrm{i}}>\mathrm{L}_{\mathrm{ij}}$ rata-rata

$$
\left(\mathrm{C}_{\mathrm{i}} / \mathrm{L}_{\mathrm{ij}}\right)_{\text {baru }}=\frac{\left[\mathrm{C}_{\mathrm{i}}-\left(\mathrm{L}_{\mathrm{ij}}\right)_{\text {rata-rata }}\right]}{\left\{\left(\mathrm{L}_{\mathrm{ij}}\right)_{\text {maksimum }}-\left(\mathrm{L}_{\mathrm{ij}}\right)_{\text {rata-rata }}\right\}}
$$

4. Jika hasil $\mathrm{Ci} / \mathrm{Lij}$ lebih dari 1 :

$$
\left(\mathrm{C}_{\mathrm{i}} / \mathrm{L}_{\mathrm{ij}}\right)_{\text {baru }}=1,0+\mathrm{P} \cdot \log \left(\mathrm{C}_{\mathrm{i}} / \mathrm{L}_{\mathrm{ij}}\right)_{\text {hasil pengukuran }}
$$

5. Nilai Indeks Pencemaran :

$$
\mathrm{PI}_{\mathrm{j}}=\sqrt{\frac{\left(\mathrm{C}_{\mathrm{i}} / \mathrm{L}_{\mathrm{ij}}\right)_{\mathrm{M}}^{2}+\left(\mathrm{C}_{\mathrm{i}} / \mathrm{L}_{\mathrm{ij}}\right)_{\mathrm{R}}^{2}}{2}}
$$

$$
\begin{array}{llll}
\text { Keterangan } \quad: \quad & \mathrm{Ci} & & \text { Konsentrasi berdasarkan kualitas air } \\
\mathrm{Lij} & = & \text { Baku mutu } \\
& \mathrm{Pij} & = & \text { Indeks Pencemar }
\end{array}
$$

Penentuan status mutu air dengan metode indeks pencemaran pada umumnya dilakukan dengan membagi nilai konsentrasi parameter pencemar dengan nilai baku mutu parameter pencemar. Status mutu air terbagi dalam beberapa kategori berdasarkan nilai indeks pencemarannya yang akan di tampilkan pada Tabel 1.

Tabel 1 Penentuan Status Mutu Air [2]

\begin{tabular}{cc}
\hline Nilai Indeks & Kategori \\
\hline $0 \leq \mathrm{Pij} \leq 1$ & Memenuhi baku mutu \\
\hline $1<\mathrm{Pij} \leq 5$ & Cemar ringan \\
\hline $5<\mathrm{Pij} \leq 10$ & Cemar sedang \\
\hline $\mathrm{Pij}>10$ & Cemar berat \\
\hline
\end{tabular}

\subsection{Beban Pencemaran Eksisting}

Beban Pencemaran terbagi atas dua bagian, yaitu Beban Pencemaran Maksimum (BPM) dan Beban Pencemaran Aktual (BPA). Beban pencemaran maksimum didapat dengan mengalikan debit sungai dengan konsentrasi berdasarkan baku mutu yang berlaku, sedangkan beban pencemaran terukur didapat dengan mengalikan debit sungai dengan konsentrasi hasil pengukuran. Hasil BPA kemudian dibandingkan dengan hasil BPM sebagai baku mutu beban pencemaran. Apabila hasil dari BPA lebih besar dari BPM maka dapat dipastikan bahwa sungai Cisangkuy sudah tidak dapat lagi menampung beban pencemar. Berikut ini merupakan penjelasan BPM dan BPA [2] : 
- $\mathrm{BPM}=\mathrm{Q} \times \mathrm{C}_{\mathrm{BM}}$

dimana :

$\mathrm{BPM}=$ Beban Pencemaran Maksimum $(\mathrm{kg} / \mathrm{hari})$

$\mathrm{Q} \quad=\quad$ Debit sungai $\left(\mathrm{m}^{3} /\right.$ detik $)$

$\mathrm{C}_{\mathrm{BM}} \quad=\quad$ Konsentrasi maksimal yang terdapat pada baku mutu (mg/liter)

- $\mathrm{BPA}=\mathrm{Q} \times \mathrm{C}_{\mathrm{M}}$

dimana :

BPT $=$ Beban Pencemaran Terukur (kg/hari)

$\mathrm{Q} \quad=\quad$ Debit sungai $\left(\mathrm{m}^{3} /\right.$ detik $)$

$\mathrm{C}_{\mathrm{M}} \quad=\quad$ Konsentrasi pengukuran $(\mathrm{mg} / \mathrm{liter})$

\subsection{Potensi Beban Pencemaran Eksisting}

Perhitungan potensi beban pencemaran air dari aktivitas pertanian diperoleh dari luas lahan pertanian dan jenis penggunaan lahan di Sub DAS Cisangkuy. Selain itu harus diketahui juga perkiraan beban limbah area pertanian yang dihitung dengan menggunakan data nilai emisi pada Tabel 2.

Perhitungan Potensi Beban Pencemaran (PBP) dari beberapa jenis lahan pertanian berbeda-beda. Rumus-rumus yang digunakan di antaranya [2]:

- $\operatorname{PBP}$ sawah $=\frac{\text { luas lahan (ha) } \times \text { faktor emisi }(\mathrm{kg} / \mathrm{ha} / \mathrm{musim} \text { tanam }) \times 10 \%}{\text { jumlah hari tanam (hari) }}$

- PBP palawija dan perkebunan $=\frac{\text { luas lahan (ha) } \mathrm{x} \text { faktor emisi (kg/ha/musim tanam) } \times 1 \%}{\text { jumlah hari tanam (hari) }}$

Tabel 2 Faktor Effluent Pertanian [3]

\begin{tabular}{cccc}
\hline \multirow{2}{*}{$\begin{array}{c}\text { Limbah } \\
\text { Pertanian }\end{array}$} & \multicolumn{3}{c}{ Faktor Effluent $\mathbf{( k g / h a / m u s i m ~ t a n a m )}$} \\
\cline { 2 - 4 } & Sawah & Palawija & $\begin{array}{c}\text { Perkebunan } \\
\text { lain }\end{array}$ \\
\hline BOD & 225 & 125 & 32,5 \\
\hline $\mathbf{N}$ & 20 & 10 & 3 \\
\hline $\mathbf{P}$ & 10 & 5 & 1,5 \\
\hline TSS & 0,04 & 2,4 & 1,6 \\
\hline Pertisida & 0,16 & 0,08 & 0,024 \\
\hline
\end{tabular}

\subsection{Gambaran Umum Wilayah Studi}

\section{HASIL DAN PEMBAHASAN}

Kecamatan-kecamatan yang masih memiliki lahan pertanian di antaranya yaitu Kecamatan Baleendah, Arjasari, Cangkuang, Banjaran, Pangalengan, dan Cimaung. Kecamatan Pangalengan merupakan kecamatan dengan luas terbesar dalam Sub DAS Cisangkuy yaitu sebesar 12.272,46 ha. Sedangkan kecamatan yang memiliki luas lahan sawah terbesar adalah Kecamatan Cimaung sebesar 2.766,95 ha dan kecamatan dengan luas lahan kebun terbesar adalah Kecamatan Pangalengan sebesar 4.303,14 ha [1]. 


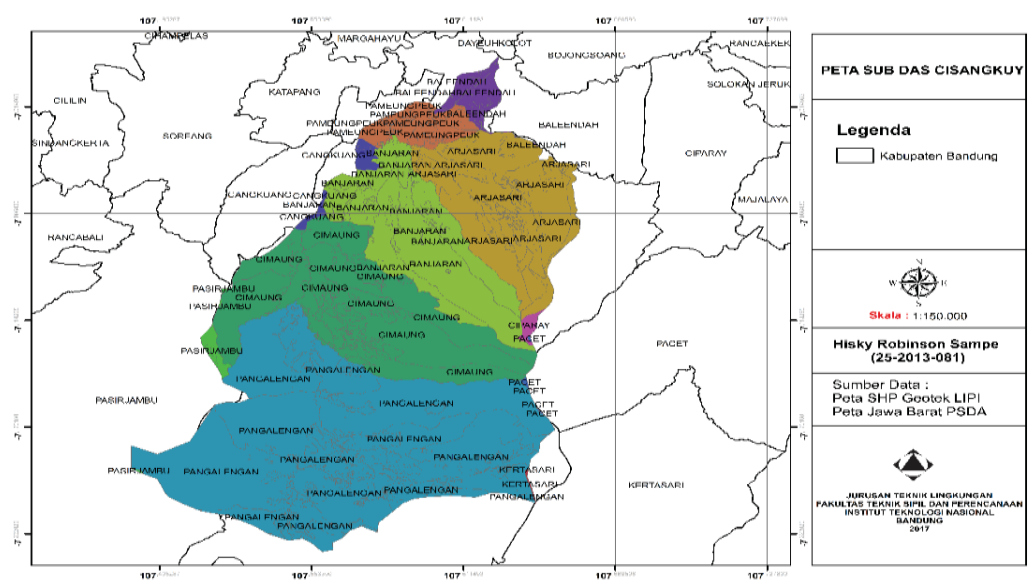

Gambar 1 Sub DAS Cisangkuy

\subsection{Status Mutu Air Sungai Cisangkuy}

Penentuan status mutu air sungai Cisangkuy didapatkan berdasarkan hasil perhitungan dengan menggunakan indeks pencemaran. Data terakhir kualitas air yang diperoleh yaitu data tahun 2016 yang terdiri atas bulan Juni, Agustus, Oktober, November, dan Desember. Daftar kualitas air sungai Cisangkuy rata-rata setiap tahun dan perbandingannya selama lima tahun terakhir dapat di lihat pada Tabel 3.

Tabel 3 Kualitas Air Rata-rata Sungai Cisangkuy Periode 2011-2016 [1]

\begin{tabular}{|c|c|c|c|c|c|c|c|c|}
\hline \multirow[b]{2}{*}{ No } & \multirow[b]{2}{*}{$\begin{array}{c}\text { Parameter } \\
\text { (satuan) }\end{array}$} & \multicolumn{6}{|c|}{ Rata-rata konsentrasi } & \multirow{2}{*}{$\begin{array}{c}\text { Standar Baku Mutu } \\
\text { SK Gub Jabar } \\
39 / 2000 \\
\end{array}$} \\
\hline & & 2011 & 2012 & 2013 & 2014 & 2015 & 2016 & \\
\hline 1 & Suhu $\left({ }^{\circ} \mathrm{C}\right)$ & 24,5 & 21,3 & 22,7 & 23,85 & - & 22,98 & 25 \\
\hline 2 & $\begin{array}{c}\text { Residu } \\
\text { Terlarut } \\
\text { (mg/liter) } \\
\end{array}$ & 52 & 62 & 80 & 54,67 & 116,5 & 52,6 & 1.000 \\
\hline 3 & $\begin{array}{l}\text { Residu } \\
\text { Tersupensi } \\
\text { (mg/liter) }\end{array}$ & 17,5 & 9,1 & 13,9 & 19,97 & 55,58 & 41,04 & - \\
\hline 4 & $\begin{array}{c}\text { Kekeruhan } \\
\text { (NTU) }\end{array}$ & $\mathbf{8 9 , 7}$ & 30,2 & 96,9 & 229,5 & $\mathbf{2 7 , 5 5}$ & 54,78 & 5 \\
\hline 5 & $\begin{array}{l}\text { Daya Hantar } \\
\text { Listrik } \\
(\mu \mathrm{mhos} / \mathrm{cm}) \\
\end{array}$ & 114,7 & 113 & 141 & 108 & 249,2 & 107 & 2.250 \\
\hline 6 & $\begin{array}{l}\text { Derajat } \\
\text { Keasaman } \\
(\mathrm{pH}) \\
\end{array}$ & 6,79 & 6,58 & 7,15 & 7,163 & 6,97 & 7,518 & 7,5 \\
\hline 7 & $\begin{array}{c}\text { Nitrit } \\
\text { (mg/liter) }\end{array}$ & 0,056 & $\mathbf{0 , 0 7 7}$ & 0,06 & 0,112 & 0,42 & 0,065 & 0,06 \\
\hline 8 & $\begin{array}{c}\mathrm{NH}_{3} \mathrm{~N} \text { bebas } \\
\text { (mg/liter) }\end{array}$ & $\mathbf{0 , 5 8}$ & 0 & 0,003 & 0,035 & 1,659 & 0,003 & 0,02 \\
\hline 9 & Besi (mg/liter) & 1,28 & 0,639 & 0,758 & 0,317 & 0,155 & 0,144 & 5 \\
\hline 10 & $\begin{array}{l}\text { Mangan } \\
\text { (mg/liter) }\end{array}$ & 0,24 & 0,206 & 0,236 & 0,174 & 0,107 & 0,14 & 0,5 \\
\hline 11 & $\begin{array}{c}\text { Seng } \\
\text { (mg/liter) }\end{array}$ & 0,004 & 0,024 & 0,012 & 0,024 & 0,011 & 0,054 & 0,02 \\
\hline 12 & $\begin{array}{l}\text { Kadmium } \\
(\mathrm{mg} / \text { liter })\end{array}$ & 0,007 & - & - & 0,026 & 0,017 & 0,025 & 0,01 \\
\hline 13 & $\begin{array}{c}\text { Krom } \\
\text { (mg/liter) }\end{array}$ & 0,002 & - & - & - & 0,015 & 0,005 & 0,05 \\
\hline 14 & Sulfat & 9,02 & - & 500 & 5,897 & 13,38 & 5,594 & 400 \\
\hline
\end{tabular}


Hisky Robinson Sampe, Iwan Juwana, Dyah Marganingrum

\begin{tabular}{|c|c|c|c|c|c|c|c|c|}
\hline \multirow[b]{2}{*}{ No } & \multirow[b]{2}{*}{$\begin{array}{l}\text { Parameter } \\
\text { (satuan) }\end{array}$} & \multicolumn{6}{|c|}{ Rata-rata konsentrasi } & \multirow{2}{*}{$\begin{array}{c}\text { Standar Baku Mutu } \\
\text { SK Gub Jabar } \\
39 / 2000\end{array}$} \\
\hline & & 2011 & 2012 & 2013 & 2014 & 2015 & 2016 & \\
\hline & (mg/liter) & & & & & & & \\
\hline 15 & $\begin{array}{l}\text { Flourida } \\
\text { (mg/liter) }\end{array}$ & 0,156 & 0,104 & 0,122 & 0,127 & 0,359 & 0,101 & 1,5 \\
\hline 16 & $\begin{array}{c}\text { Klorida } \\
\text { (mg/liter) }\end{array}$ & 5,27 & 3,01 & 5,97 & 3,077 & 37,2 & 3,446 & 600 \\
\hline 17 & $\begin{array}{c}\text { BOD } \\
\text { (mg/liter) }\end{array}$ & 2,92 & 2,42 & 6,3 & 2,737 & 70,87 & 3,724 & 6 \\
\hline 18 & $\begin{array}{c}\mathrm{COD} \\
\text { (mg/liter) }\end{array}$ & 19,35 & 9,7 & 22,2 & $\mathbf{5 8 , 5 7}$ & 157 & 17,44 & 10 \\
\hline 19 & DO (mg/liter) & 6,035 & 6,21 & 5,09 & 6,38 & 3,52 & 6,612 & 3 \\
\hline 20 & $\begin{array}{c}\text { Detergen } \\
\text { sebagai } \\
\text { MBAS } \\
\text { (mg/liter) }\end{array}$ & 0,05 & 0,084 & 0,113 & 0,105 & 0,636 & 0,202 & 0,5 \\
\hline 21 & $\begin{array}{c}\text { Fecal } \\
\text { Coliform } \\
\text { (jml/100 ml) }\end{array}$ & 110.000 & 13.600 & 210 & 3.620 & $11.529 .375,8$ & 603,3 & 2.000 \\
\hline
\end{tabular}

Parameter kekeruhan merupakan parameter yang melebihi baku mutu selama tahun 2011-2016. Tingginya nilai kekeruhan di Sungai Cisangkuy lebih di sebabkan oleh tingginya parameter fecal coliform yang dominan selama tahun 2011-2016 dari buangan limbah domestik dan peternakan, juga beberapa parameter yang melebihi baku mutu di tahun tertentu seperti nitrit, amonia bebas, kadmium, COD, dan deterjen. Parameter nitrit dan amonia merupakan parameter yang saling berhubungan terutama adalam proses nitrifikasi di Sungai Cisangkuy. Sumber amonia berasal dari dekomposisi bahan organik oleh mikroba. Bahan organik ini termasuk biota air atau tumbuhan air yang telah mati [4]. Apabila nilai amonia tinggi artinya di Sungai Cisangkuy belum terjadi proses nitrifikasi dari amonia ke nitrit. Begitu juga dengan tingginya konsentrasi nitrit di sebabkan oleh proses nitrifikasi yang tidak berjalan sempurna, yang menyebabkan proses oksidasi dari nitrit ke nitrat menjadi terhambat. Kadmium merupakan senyawa toksik yang tidak dapat larut dalam air. Untuk kepentingan pertanian, nilai kadmium tidak boleh melebihi $0,05 \mathrm{mg} /$ liter karena dapat berpengaruh pada pertumbuhan padi. Kandungan COD yang tinggi di sebabkan oleh banyaknya zat organik yang terdapat di Sungai Cisangkuy. Untuk kepentingan pertanian parameter COD di Sungai Cisangkuy tidak boleh mencapai nilai yang tinggi. Gambar 2 menyajikan parameter kualitas air yang tidak memenuhi baku mutu di Sungai Cisangkuy pada tahun 2011-2016. Setelah di ketahui nilai indeks pencemaran dan status mutu air sungai Cisangkuy tahun 2016, kemudian di bandingkan dengan nilai indeks pencemaran lima tahun terakhir untuk melihat trend pencemaran di sungai Cisangkuy. 

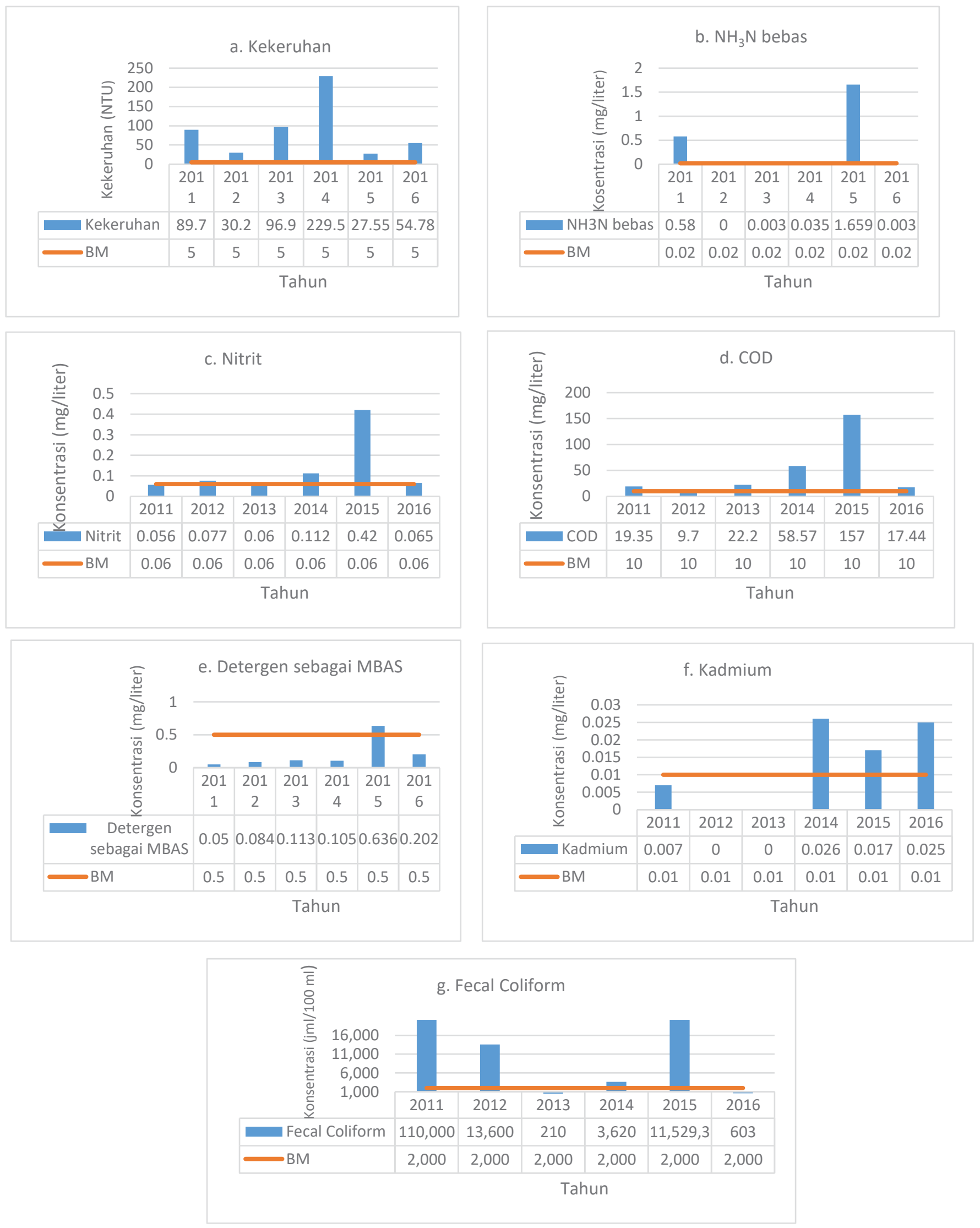

Gambar 2 Parameter Kualitas Air yang Tidak Memenuhi Baku Mutu SK. Gubernur Jawa Barat No.39 Tahun 2000 di Sungai Cisangkuy Tahun 2011-2016 
Setelah didapatkan data indeks pencemaran dan status mutu air masing-masing bulan, perlu juga dilakukan perhitungan indeks pencemaran dan penentuan status mutu air rata-rata tahunan yang datanya diperoleh dari rata-rata kualitas air dari bulan Juni, Agustus, Oktober, November, dan Desember. Data indeks pencemaran rata-rata ini digunakan untuk membandingkan indeks pencemaran rata-rata lima tahun terakhir.

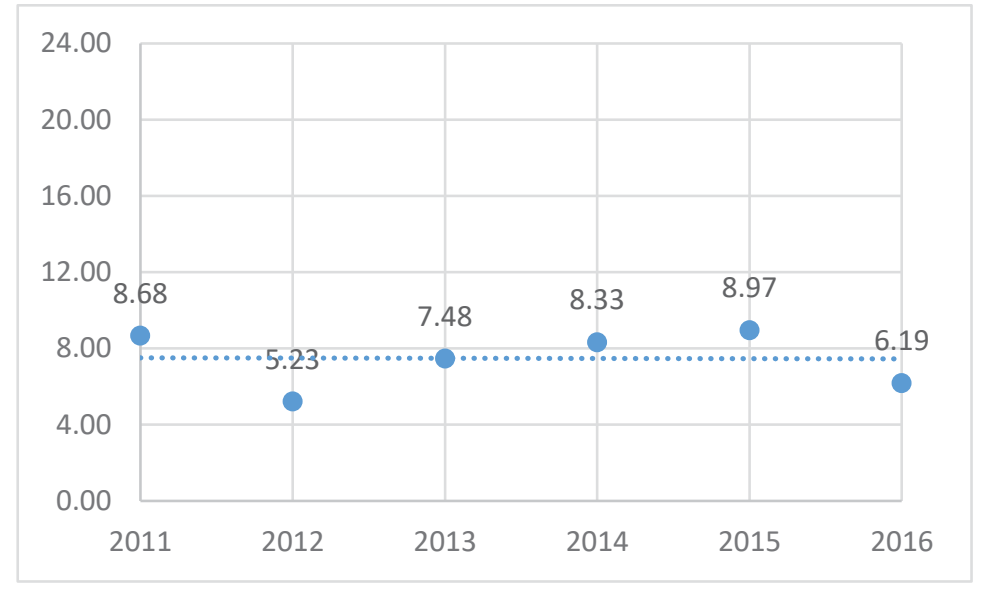

Gambar 3 Indeks Pencemaran Sungai Cisangkuy Tahun 2011-2016

Indeks pencemaran tahunan di peroleh dengan merata-ratakan nilai IP pada setiap bulan sampling. Pada IP tahunan terlihat bahwa dari tahun 2011 sampai 2016 menunjukkan bahwa trend pencemaran di Sungai Cisangkuy cenderung stabil. Jika di lihat dari kelas mutu air, IP dari tahun 2011 sampai 2016 termasuk dalam kategori cemar sedang. Pada grafik diatas nilai IP di setiap tahun dianggap sudah mewakili nilai IP ketika musim hujan dan musim kemarau. Terdapat kendala dalam menentukan IP saat musim hujan dan kemarau yaitu kurang lengkapnya data bulan sampling pada musim hujan maupun musim kemarau. Nilai IP pada saat musim hujan maupun musim kemarau bisa setiap saat berubah. Nilai IP pada saat musim hujan biasanya akan cenderung lebih tinggi di bandingkan dengan nilai IP pada saat musim kemarau. Hal ini di sebabkan karena pada saat musim hujan, debit sungai akan meningkat sehingga akan terjadi turbulensi di sungai yang menyebabkan pencemaran sungai meningkat yang berpengaruh pada tingginya nilai IP. Sedangkan pada saat musim kemarau terdapat proses aerasi yang berasal dari sinar matahari yang membuat kadar oksigen di air sungai meningkat. Kadar oksigen ini yang akan mengoksidasi zat organik di sungai yang menyebabkan pencemaran sungai menurun yang berpengaruh juga pada rendahnya nilai IP di Sungai Cisangkuy.

\subsection{Beban Pencemaran Eksisting}

Berdasarkan hasil pengukuran kualitas air pada tahun 2016, Sungai Cisangkuy termasuk dalam kategori cemar ringan. Meskipun termasuk dalam kategori cemar ringan, perlu dilakukan juga perhitungan beban pencemaran eksisting sungai Cisangkuy pada tahun 2016 untuk mengetahui total beban pencemaran maksimum yang dapat ditampung oleh badan air sungai serta total beban pencemaran terukur yang ada di badan sungai Cisangkuy

Jika di bandingkan antara BPM dan BPA Sungai Cisangkuy, dapat di lihat bahwa parameter COD melebihi BPM Sungai Cisangkuy sehingga Sungai Cisangkuy sudah tidak dapat menampung beban pencemaran parameter COD. Selain itu parameter amonia dan nitrit juga melebihi BPM Sungai Cisangkuy. Hanya parameter BOD saja yang masih memenuhi BPM Sungai Cisangkuy pada tahun 2016. Pada parameter P tidak terdapat data konsentrasi terukur dan BPA. Hal ini di sebabkan karena tidak di lakukan pengukuran parameter pospat oleh BBWS Citarum. 


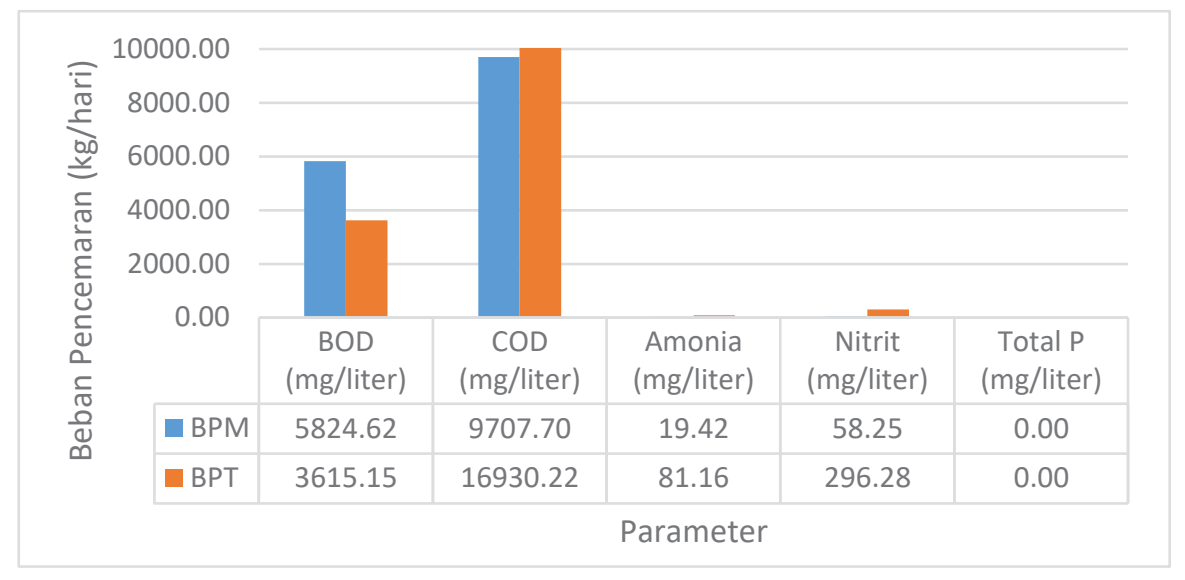

Gambar 4 Perbandingan BPM dan BPA Sungai Cisangkuy

\subsection{Potensi Beban Pencemaran (PBP)}

Potensi beban pencemaran dari sektor pertanian di pengaruhi oleh luas lahan yang terdapat pada kawasan sub DAS Cisangkuy dan juga jenis lahan pertaniannya, apakah itu termasuk ke golongan sawah, tanaman perkebunan, atau palawija. Penentuan luas lahan diperoleh dari hasil digitasi dan analisis software ArcGIS kemudian menjumlahkan luas lahan yang terdapat di masing-masing kecamatan. Pada Tabel 4 akan ditampilkan daftar kecamatan beserta luas lahan pertanian yang ada pada area sub DAS Cisangkuy.

Berikut ini merupakan contoh perhitungan beban pencemaran sektor pertanian untuk lahan sawah tahun 2016 di Kecamatan Arjasari dengan parameter BOD [6] :

- $\quad$ PBP Sawah Tahun 2016

Dengan menggunakan rumus persamaan (9), maka diperoleh hasil BP sawah 2016 di Kecamatan Arjasari yaitu sebesar 296,07 kg/hari atau sama dengan 0,296 ton/hari.

Tabel 4 Daftar Luas Lahan Pertanian Sub DAS Cisangkuy Berdasarkan Kecamatan Tahun 2016

\begin{tabular}{cccccc}
\hline \multirow{2}{*}{ No } & Nama & \multicolumn{2}{c}{ Luas lahan 2016 (ha) } & \multicolumn{2}{c}{ Persentase (\%) } \\
\cline { 3 - 6 } & Kecamatan & Sawah & Kebun & Sawah & Kebun \\
\hline 1 & Baleendah & 158,59 & 41 & 33,32 & 8,61 \\
\hline 2 & Pameungpeuk & - & - & 0 & 0 \\
\hline 3 & Arjasari & 2394,86 & 460,93 & 59,42 & 11,44 \\
\hline 4 & Cangkuang & 1265,91 & 16,63 & 679,06 & 8,92 \\
\hline 5 & Banjaran & 2599,37 & 743,17 & 68,68 & 19,64 \\
\hline 6 & Ciparay & - & - & 0,00 & 0,00 \\
\hline 7 & Pangalengan & 1357,32 & 4303,14 & 11,06 & 35,06 \\
\hline 8 & Pacet & - & - & 0,00 & 0,00 \\
\hline 9 & Cimaung & 2766,95 & 671,33 & 50,31 & 12,21 \\
\hline 10 & Pasirjambu & - & 15,97 & 0,00 & 11,80 \\
\hline Total Luas Lahan & 10543 & 6252,17 & 38,66 & 22,93 \\
\hline
\end{tabular}

Sumber: Hasil Analisis, 2017

Faktor emisi untuk sawah dengan parameter BOD yaitu sebesar $225 \mathrm{~kg} / \mathrm{ha} / \mathrm{musim}$ tanam. Pengalian dengan 10\% merupakan jumlah beban pencemaran sawah yang masuk ke sungai [5]. 182 hari/tahun merupakan jumlah hari panen sawah yang merupakan bagian dari dua kali panen padi dalam setahun [6].

Berdasarkan hasil digitasi dan analisis software ArcGIS, daerah sekitar sub DAS Cisangkuy hanya memiliki lahan sawah dan kebun/perkebunan. Menurut Iskandar [3], jumlah faktor emisi lahan kebun/palawija berbeda dengan perkebunan. Dalam kasus ini, berdasarkan peta tata guna lahan Jawa 
Barat yang diperoleh dari Dinas PSDA, lahan kebun digabungkan dengan perkebunan dan tidak memiliki lahan palawija. Oleh karena itu dilihat dari besarnya nilai faktor emisi, maka dipilihlah faktor emisi kebun/palawija untuk mengetahui beban pencemaran dari kebun/perkebunan. Berikut ini adalah salah satu contoh perhitungan beban pencemaran sektor pertanian untuk lahan kebun/perkebunan di Kecamatan Banjaran dengan parameter BOD [6]:

- $\quad$ PBP Kebun Tahun 2016

Dengan menggunakan rumus persamaan (2.10), maka diperoleh hasil BP kebun 2016 di Kecamatan Banjaran yaitu sebesar 7,61 kg/hari atau sama dengan 0,007 ton/hari.

Untuk kasus lahan kebun/perkebunan memiliki hari tanam 122 hari/tahun. Hal ini berdasarkan pada musim tanam kebun/perkebunan sebanyak tiga kali dalam setahun [6]. Pengalian dengan $1 \%$ adalah merupakan jumlah beban pencemar yang masuk dari lahan kebun/perkebunan. Apabila hasil dari beban pencemaran sektor pertanian dari kedua jenis lahan pertanian ini, terlihat bahwa beban pencemaran kebun/perkebunan lebih kecil dibandingkan dengan beban pencemaran dari sawah. Hal ini disebabkan oleh perbedaan standar faktor emisi dari setiap jenis lahan pertanian dengan masingmasing parameternya. Selain itu, jumlah lahan juga sangat mempengaruhi besarnya beban pencemaran dari sektor pertanian. Semakin besar suatu lahan, semakin besar pula beban pencemaran yang dihasilkan.

Berikut ini merupakan rekapitulasi potensi beban pencemaran lahan pertanian dari dua jenis lahan pertanian tahun 2016 yang terdapat pada Tabel 5 berikut ini:

Tabel 5 Rekapitulasi Beban Pencemaran Sektor Pertanian Sungai Cisangkuy Tahun 2016

\begin{tabular}{|c|c|c|c|c|c|c|c|c|}
\hline \multirow{2}{*}{ No } & \multirow{2}{*}{$\begin{array}{c}\text { Nama } \\
\text { Kecamatan }\end{array}$} & \multicolumn{3}{|c|}{ Sawah (ton/hari) } & \multicolumn{3}{|c|}{ Kebun (ton/hari) } & \multirow{2}{*}{$\begin{array}{c}\text { Total } \\
\text { (ton/hari } \\
\text { ) }\end{array}$} \\
\hline & & BOD & $\mathbf{N}$ & $\mathbf{P}$ & BOD & $\mathbf{N}$ & $\mathbf{P}$ & \\
\hline 1 & Baleendah & 0,02 & 0,002 & 0,001 & 0,000 & 0,00 & 0,00 & 0,02 \\
\hline 2 & Pameungpeuk & - & - & - & - & - & - & 0,00 \\
\hline 3 & Arjasari & 0,30 & 0,03 & 0,01 & 0,00 & 0,00 & 0,00 & 0,34 \\
\hline 4 & Cangkuang & 0,16 & 0,01 & 0,01 & 0,00 & 0,00 & 0,00 & 0,18 \\
\hline 5 & Banjaran & 0,32 & 0,03 & 0,01 & 0,01 & 0,00 & 0,00 & 0,37 \\
\hline 6 & Ciparay & - & - & - & - & - & - & 0,00 \\
\hline 7 & Pangalengan & 0,17 & 0,01 & 0,01 & 0,04 & 0,00 & 0,00 & 0,24 \\
\hline 8 & Pacet & - & - & - & - & - & - & 0,00 \\
\hline 9 & Cimaung & 0,34 & 0,03 & 0,02 & 0,01 & 0,00 & 0,00 & 0,40 \\
\hline 10 & Pasirjambu & - & - & - & - & - & - & 0,00 \\
\hline & Subtotal & 1,30 & 0,12 & 0,06 & 0,06 & 0,01 & 0,00 & 1,55 \\
\hline
\end{tabular}

Apabila Beban Pencemaran Sektor Pertanian ini dibandingkan dengan BPM rata-rata Sungai Cisangkuy tahun 2016, total beban pencemaran sektor pertanian baik lahan sawah maupun kebun di Sungai Cisangkuy yang melewati sepuluh kecamatan yaitu sebesar 1,55 ton/hari. Jika dilihat dari masing-masing parameter, parameter BOD baik sawah dan kebun masih dapat memenuhi beban pencemaran Sungai Cisangkuy karena beban pencemaran BOD pertanian, baik dari sawah maupun kebun, bernilai 1,36 ton/hari. Sedangkan BPM Sungai Cisangkuy untuk parameter BOD bernilai 5,82 ton/hari. Hal ini disebabkan oleh besarnya luas lahan yang berdampak pada tingginya beban pencemaran, sedangkan nilai baku mutu yang ditetapkan untuk parameter total $\mathrm{N}$ lebih kecil seiring dengan ketatnya peraturan yang digunakan, yaitu SK. Gub. Jabar No. 39 Th. 2000 [7]. 


\section{KESIMPULAN}

Berdasarkan hasil dan pembahasan mulai dari penentuan status mutu air hingga perhitungan potensi beban pencemaran di sungai Cisangkuy, kualitas air Sungai Cisangkuy ini tidak memenuhi baku mutu, artinya kualitas air Sungai Cisangkuy selama rentang waktu 5 tahun terakhir tergolong dalam kategori cemar sedang. Trend indeks pencemaran Sungai Cisangkuy cenderung stabil karena setiap tahun tidak menunjukkan perubahan signifikan. BPA rata-rata yang masuk ke Sungai Cisangkuy pada tahun 2016 melebihi BPM yang ditetapkan. Tetapi berbeda dengan beban pencemaran dari sektor pertanian, dimana ada salah satu parameter, yaitu BOD, yang masih dapat memenuhi beban pencemaran Sungai Cisangkuy karena memiliki nilai total beban pencemarannya yaitu 1,36 ton/hari, sedangkan BPM Sungai Cisangkuy memiliki kemampuan menampung beban pencemaran sebesar 5.82 ton/hari, sehingga Sungai Cisangkuy masih dapat menampung beban pencemaran BOD dari sawah dan kebun.

\section{DAFTAR PUSTAKA}

[1] Lembaga Ilmu Pengetahuan Indonesia. 2017. Peta SHP Sub DAS Citarum Hulu. Bandung: Pusat Penelitian Geoteknologi, Lembaga Ilmu Pengetahuan Indonesia.

[2] Anonim. 2003. Keputusan Menteri Lingkungan Hidup Nomor 115 Tahun 2003 tentang Pedoman Penentuan Status Mutu Air.

[3] Iskandar. 2007. Panduan Pelatihan Pengelolaan Kualitas Air. Jakarta: Puslitbang Sumber Daya Air Kementerian Pekerjaan Umum.

[4] Effendi, Hefni. 2003. Telaah Kualitas Air: Bagi Pengelolaan Sumber Daya dan Lingkungan Perairan. Kanisius.

[5] Balai Lingkungan Keairan Pusat Litbang Sumber Daya Air. 2010. Inventarisasi \& Indentifikasi Sumber dan Beban Pencemaran Air. Bandung: Pusat Litbang Sumber Daya Air.

[6] Jurnal Litbang Pertanian. 2016. (diakses tanggal 15 Oktober 2017)

[7] Anonim. 2000. Surat Keputusan Gubernur Jawa Barat Nomor 39 Tahun 2000 tentang Peruntukan Air dan Baku Mutu Air pada Sungai Citarum dan Anak-anak Sungainya di Jawa Barat.

[8] Anonim. 2009. Undang-undang Republik Indonesia Nomor 32 Tahun 2009 tentang Perlindungan dan Pengelolaan Lingkungan Hidup.

[9] Anonim. 2011. Peraturan Daerah Kota Bandung Nomor 18 Tahun 2011 tentang Rencana Tata Ruang Wilayah Kota Bandung Tahun 2011-2031.

[10] Anonim. 2016. Peraturan Daerah Kabupaten Bandung Nomor 27 Tahun 2016 tentang Rencana Tata Ruang Wilayah Kabupaten Bandung Tahun 2016-2036.

[11] Fresenius, W., Quentin, K.E. dan Schneider, W. (editor). 1988. Water Analysis. Springer-Verlag Berlin Heidelberg, Jerman.

[12] Kurniasih, N. 2002. Pengelolaan DAS Citarum berkelanjutan. Jurnal Teknologi Lingkungan, 3(2), 82-91.

[13] Riayatulloh, M.S., Wardhani, E., dan Pharmawati, K. 2017. Analisis Kualitas Air Sungai Cilaki Sebagai Sumber Air Baku untuk PDAM Kota Bandung. Jurnal Rekayasa Lingkungan. 